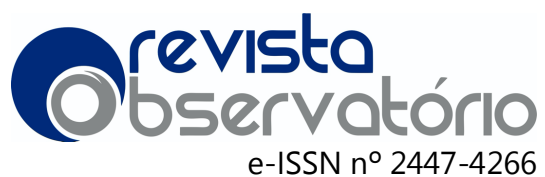

Vol. 6, n. 1, January-March. 2020

\section{Learning of teaching: A look at teacher education of the Communication professors in the UFRR}

Aprendizagem da docência: Um olhar para a formação docente dos professores do campo da Comunicação na UFRR

Aprendizaje docente: Una mirada a la formación docente de docentes en el campo de la Comunicación en la UFRR

\section{Leila Adriana Baptaglin}

Doctor in Education (UFSM). Research professor in the Licentiate Course in Visual Arts, the Postgraduate Program in Communication, the Postgraduate Program in Education, both at UFRR, and in the Interinstitutional Doctorate in Education in the Amazon. leila.baptaglin@ufrr.br.

(D) 0000-0002-8137-0913

\section{Vilso Junior Santi}

Doctor in Social Communication (PUC-RS). Research professor in the Course of Social Communication/Journalism and in the Postgraduate Program in Communication at UFRR. vjrsanti@gmail.com.

(D) 0000-0003-0970-6459

Mailing address: Universidade Federal de Roraima, Reitoria. Avenida Capitão Ene Garcez - de 1985 ao fim - lado ímpar. Aeroporto. 69310000 - Boa Vista, RR Brasil.

\begin{abstract}
:
This research aims to discuss teacher education implemented in the construction of the learning of teaching of the professors in the Bachelor's Course in Social Communication/Journalism (CCOS) and the Postgraduate Program in Communication (PPGCOM) in the Federal University of Roraima (UFRR). For this, we analyzed the resumés in the Lattes platform and an inquiry via email to the teachers asking them about the activities they performed during their education process, related to the learning of teaching. This set of documents was studied through the Content Analysis, in which three categories were defined: Initial academic education; Postgraduate studies; and Educational trajectories. The discussion of the data makes it clear that while teachers are educators, they are also educated and this process requires a collaborative posture that is done in the classroom, it is a social, shared achievement. The process of learning of teaching, therefore, places the teacher in face of a challenge of using strategies to favor the mastery of specific knowledge, articulating with the pedagogical dimension, even if for that they need to have educational experiences other than necessarily go through formal education.

KEYWORDS: Learning of teaching; Teacher education; Communication; Amazon Knowledge; Federal University of Roraima.
\end{abstract}

Accepted: 12.12 .2019

Published: 03.01.2020.

\section{Introduction}

As a reference in formal education and training in the state of Roraima, the Federal University of Roraima (UFRR) has played an essential role in the qualification of professionals working in the state.

The UFRR was established in September 1989 and, as expressed in its Statute (2003), is based on the constitutional principle of indissociability between education, research, 


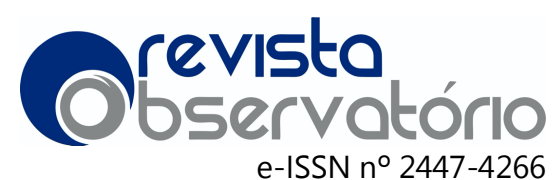

Vol. 6, n. 1, January-March. 2020

and extension, and it has guaranteed by the Constitution of Brazil its educational, scientific, administrative, financial and patrimonial autonomy.

The Statute of the UFRR (2003) also states its institutional purpose, which is to produce, integrate and socialize knowledge to ensure citizens are committed with the cultural, social, economic and environmental development. Hence, the UFRR has as goals to promote and disseminate education, cultural creation and the scientific and reflexive development of society, guaranteeing its quality and its public nature. Furthermore, the Institution aims to form citizens, in different areas of knowledge, with scientific spirit and reflective thinking, fit for professional work, as a foundation for the sustainable development of the local, regional and national societies, cooperating with their lifelong learning; to provide the community with free and high quality elementary, secondary and higher education, including Undergraduate and Graduate studies; and to produce scientific and technological research, as a support for the economic and social sustainable development in the State of Roraima, the Amazon Region and Brazil, grounded on the ethical and ethnic values, with emphasis on environmental preservation.

The UFRR establishes guidelines for research, education, and extension in its Institutional Development Plan (2016-2019). Regarding education, the subject of this study, it foresees it as macroprocesses: advance in high-quality education; strengthen the culture of transdisciplinary curricula; expand partnerships with public and private institutions; expand and strengthen the Undergraduate and Postgraduate Courses; increase the grades of the Undergraduate and Postgraduate courses; and strengthen the education support units and programs.

The Institution, its Centers and Institutes are located in the northernmost region of the Brazilian Amazon, in a tri-border geopolitical context (Brazil - Venezuela - Guyana) that is characterized by its cultural and natural treasures, thus expanding the possibilities and difficulties of its activity.

Given the latent concerns about Higher Education, which consequently affect the UFRR, we have teacher training in all different areas. In this regard, our goal in this study is to discuss teacher education implemented in the construction of learning of teaching for the professors who work in the bachelor's course of Social Communication/Journalism (CCOS) and the Communication Postgraduate Program (PPGCOM) in the UFRR.

To consolidate this study, we start from a qualitative and quantitative look at the data in the resume of the teachers of the CCOS and the PPGCOM in the Lattes platform and an inquiry via email with the teachers regarding activities conducted during their education that relates to the learning of teaching. This set of documents was studied 


\section{revisto \\ Observatório \\ e-ISSN no 2447-4266}

Vol. 6, n. 1, January-March. 2020

through Content Analysis, in order to specify, in categories, elements that enable us to identify some of the main educational processes developed for the learning of teaching by the analyzed faculty members.

For Bardin (2011), content analysis is

a set of communication analysis techniques aiming to obtain systematic and objective procedures for describing the content of indicator messages (quantitative or not) that allow the inference of knowledge related to the production/reception conditions (inferred variables) of these messages (BARDIN, 2011, p. 48). ${ }^{1}$

These techniques involve the organization of the analysis categories, which are linked to the goal of this study - in this case, to present teacher education conducted in the construction of the UFRR's CCOS and PPGCOM faculty member's learning of teaching.

It is worth mentioning that the Social Communication/Journalism Course (CCOS) is an Undergraduate Course whose bachelors are professionals who work exclusively in journalism, considering the specificities of the regional market. As it appears in the CCOS's Course Pedagogical Project (2015), it was established in 1991 and it has today a semiannual school regime, with a standard completion time of 4 years, and with its classes being held during nighttime.

The CCOS proposes to train professionals with ethical, critical, theoretical, technical and technological competence to work responsibly, emphasizing, on the one hand, the production and management of journalistic information and, on the other, the scientific domain.

The Communication Postgraduate Program (PPGCOM), however, has its origin linked to the history of the UFRR itself, and to the Undergraduate Courses that lent human resources to its creation project (especially the Bachelor's Course in Social Communication/Journalism itself, the Licentiate Course in Visual Arts, and the Licentiate Course in Music).

The PPGCOM's main goal, according to its Regiment (2018), is to consolidate research in the area of Communication, Territorialities, and Amazonian Knowledge,

\footnotetext{
${ }^{1}$ um conjunto de técnicas de análise das comunicações visando obter por procedimentos sistemáticos e objetivos de descrição do conteúdo das mensagens indicadores (quantitativos ou não) que permitam a inferência de conhecimentos relativos às condições de produção/recepção (variáveis inferidas) dessas mensagens (BARDIN, 2011, p. 48).
} 


\section{Orevisto \\ e-ISSN n०2447-4266}

Vol. 6, n. 1, January-March. 2020

working towards the qualification of human resources for teaching, research and the sustainable development to meet the regional needs.

We can see, then, that both the objectives of the CCOS and the PPGCOM are not clear as to what their commitment to educating teachers is. However, we can see, not only in Roraima, that a significant portion of professionals who target their qualifications to Master's and Doctoral degrees end up entering the academic space of the Higher Education Institutions (HEI) to act as teachers. Given this targeting, the lack of an initial teacher education emerges as a factor to be considered, and with this the need to generate other education processes to meet this demand.

It is worth noting that this view is not specific to the courses related to the areas of Communication and Information Sciences, but common to a wide range of areas of knowledge that, in their initial education stages, are not concerned with activities aimed at learning of teaching, and that in their professional activities they end up entering the specificities of teaching to coordinate teaching and learning processes in their fields of knowledge.

\section{State of knowledge}

When entering the specificity of teacher education, we seek to recognize in some channels how this topic has been discussed. Thus, in the publications of the Catalog of Dissertations and Theses of the Coordination for the Improvement of Higher Education Personnel (Capes), learning of teaching and teacher education are important subjects in some works.

Regarding the research conducted on the theses defended between the years 2015 and 2018, we found 20 pieces of research that deal with the learning of teaching. Of these, none, in particular, addressed the teacher education of professionals working in Social Communication/Journalism Courses. However, we have identified works such as those of Hautrive (2016) from the Federal University of Santa Maria (UFSM) with the thesis entitled "The learning of teaching of the deaf teacher: production of knowledge about the sign language writing"2. In this work, its author discusses the process learning of teaching of deaf teachers in order to consider the knowledge and practices of signage and the writing of sign language.

\footnotetext{
2 "Aprendizagem docente do professor surdo: a produção de saberes sobre a escrita da língua de sinais"
} 


\section{Observotóńrio \\ e-ISSN no $2447-4266$}

Vol. 6, n. 1, January-March. 2020

The thesis of Sandri (2017), also from the UFSM, entitled "The learning of teaching in higher education: educational processes of professors and students in licentiate courses in the area of biological, exact and earth sciences" ${ }^{\prime 3}$ discusses the educational processes and their implication on the learning of teaching of educators and students in specific areas. The thesis of Santos (2017) from the Federal University of Paraíba (UFPB), however, is titled "The learning of teaching practice in the postgraduate program in business administration"4 and is one of the few works that address a Postgraduate Program in Business Administration, not in Education. This study presents a look at the learning of teaching in Postgraduate Courses in Business Administration in Brazil.

Regarding the learning of teaching, authors Isaia and Bolzan (2007) can be considered a reference in the theme. In their writings, they highlight the nature of the teaching profession and the conditions that establish it, considering that the learning of teaching occurs mediated by reflection, sharing and reconstruction of experiences (ISAIA and BOLZAN, 2007).

Searching for teacher education, we found 154 theses between the yeas 2017 and 2018. Of these, none, in particular, meets the specificity investigated here either. However, some studies stand out, such as the Works of Silva (2017) "Constitution of the professorship in higher education: trajectories of professors Bachelor in Administration" ${ }^{15}$ from the University of Piauí (UFPI), where its author deals with the teaching trajectory of higher education professors, more specifically professors of Administration Course.

The work of Santana (2017), "A look at the meaning of experience in teacher education"6, from the Pontifical Catholic University of Rio Grande do Sul (PUCRS), investigates how experience is structured into knowledge in teacher education. The thesis of Batista (2017) entitled "The continuing education of teachers of the Law Course and the possibilities of developing critical reflective teaching practice ${ }^{117}$ also conducted in the UFPI, discusses the teaching practice of higher education professors specifically in the Law Course.

The thesis of Debus (2017) defended in the Federal University of Santa Maria with the title "Imagination, knowledge, and actions in higher education: educational processes

\footnotetext{
3 "Aprendizagem docente no ensino superior: processos formativos de professores e estudantes nas licenciaturas da área de ciências biológicas, exatas e da terra"

4 "A aprendizagem da prática docente na pós-graduação em administração"

5 "Constituição da professoralidade no ensino superior: percursos de professores Bacharéis em Administração"

6 "Um olhar acerca do sentido da experiência na formação de professores"

7 "A formação continuada de professores do Curso de Direito e as possibilidades de desenvolvimento da prática docente reflexiva crítica"
} 


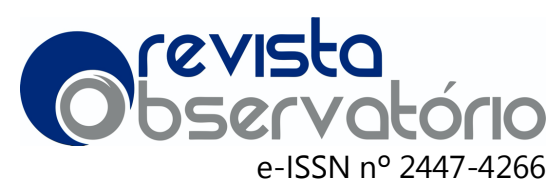

Vol. 6, n. 1, January-March. 2020

of teacher educators" ${ }^{\prime \prime}$ addressed the knowledge and practices of teacher education for professors who teach in Licentiate and Bachelor's Courses.

Starting from a brief look at these investigations, we can see that teacher education in the construction of the learning of teaching is a recurring theme in different areas of knowledge. Regarding the area of Communication and Information, more specifically in the case of the Social Communication/Journalism courses, there is the Brazilian Association of Teaching of Journalism (ABEJOR) which seeks to leverage teaching and education strategies for the professional in the area and also to discuss teaching methodologies for the learning of teaching of educators in the area.

Isaia and Bolzan (2007) point out that the teaching path is formed by a complex process that permeates moments of crisis, setbacks, advances, and discontinuities that permeate, since the choice for teaching, the initial education and the various institutions in which this professional works. Thus, the educational process experienced by the subject to have an impact on education needs an organized orientation, which follows the path traced by the teacher from their initial education to their teaching practice.

Bolzan and Isaia (2008) state that these education processes that make up the structure and the network of the teaching trajectories are echoed in the teachers' own educational trajectories. The learning of teaching then takes place through the appropriation of experiences, knowledge, skills, and attitudes that are materialized and unfolded in the relationship with others. These authors also discuss the learning of teaching as a complex process that involves knowing the teachers' personal and professional trajectories, and the educational processes as necessary factors for the comprehension of how someone learns the teaching practice (BOLZAN e ISAIA, 2008; ISAIA e BOLZAN, 2007).

Engers (2007), Pozzo (2007), Tavares (2007) and Maciel (2008), seeking to understand the learning to be a teacher, bring discussions regarding teaching and learning processes in the contemporary context. Engers (2007) states that, currently, we convey the idea that the teacher "transmits knowledge", so there is the understanding that the student "builds their own knowledge". It is not about teaching how to solve problems, but also about creating problems and questioning about a subject. The different ways of managing knowledge, therefore, range from simple techniques and skills to learning and rationality strategies (POZZO, 2007).

8 "Imaginários, saberes e fazeres no ensino superior: processos formativos do formador de professores" 


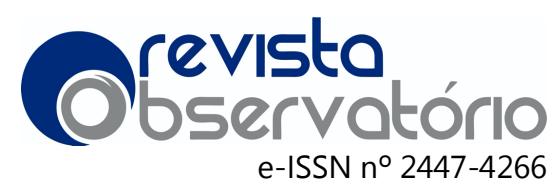

Vol. 6, n. 1, January-March. 2020

Thus, we realize that there is much to be discussed and problematized concerning the learning of teaching, especially concerning Bachelor's Courses and the performance of professors in these courses.

\section{Education and learning of teaching}

Understanding the meaning of the concept of teacher education, in this perspective, becomes essential since we are talking about something different from teaching and learning.

\footnotetext{
O sea que la enseñanza y el aprendizaje pueden entrar en la formación, pueden ser soportes de la formación, pero la formación, su dinámica, este desarrollo personal que es la formación consiste en encontrar formas para cumplir con ciertas tareas para ejercer un oficio, una profesión, un trabajo, por ejemplo (FERRY, 2004, p. 54).
}

Ferry (2004) also points out that education comes from oneself, the person is the one responsible for their own education process and finds their means to it. In other words, it is the subject who establishes his or her educational trajectories based on the experiences and directions he or she takes.

We admit, then, that the devices, the learning contents, and the curriculum are not education, but means for its accomplishment, and the way a person appropriates them, inserts themselves and enjoys these paths is what will constitute their educational trajectory. However, it is worth noting that the educational trajectories are not directly related to the intention of teaching, but they can already be present in our first educational processes, in our schooling experiences, as we are already building our conception of what it means to be a teacher.

Despite this, for Baptaglin (2017), for the educational processes to be understood and articulated with the pedagogic practice, we need times, spaces and relations with the cultural realities for the teacher and the student education to be successful. For the author, the experience is not enough, it is necessary to reflect on it, understand how it occurs at different times, spaces, and realities.

We know, though, that this is a very recent practice and that it needs the subject's awareness about their work and their becoming. This awareness, however, according to Baptaglin (2017), is still very embryonic, as it was and still is articulated by the alienating modes of production and insertion in the labor market.

From the insertion into the HEls space, Baptaglin (2017) realizes that the offered educational processes are very fragile and that the moments of debate and exchange of 


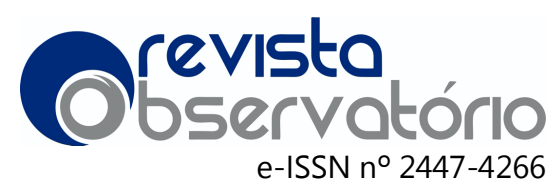

Vol. 6, n. 1, January-March. 2020

knowledge between peers are nearly non-existent. The responsibility of this situation generally falls on the teacher, who has an impression of unfinishedness, for the pursuit of his or her learning, having to enter other spaces to consolidate or deepen his or her professional development.

Still according to Baptaglin (2015), we must say that education takes place through mediation with others, through socialization. Thus, we understand that the learning of teaching occurs not only in the initial education but also in the space of the institution in which the teacher works and in so many other educational spaces, so the teacher must seek to expand their learning possibilities, building their teaching professional trajectory.

Baptaglin (2017) also tells us that it is in the teaching production space that the teacher will develop their activity articulating it with the management and the general organization of the HEl. This activity is also related to the processes of the teaching practice in action, which start to demonstrate the organization and reorganization of the didactic strategies made by the teacher. For Bolzan (2008), the understanding of these activities may imply a reflective look and redimensioning of the teacher's pedagogical actions, a situation that drives the autonomy and the search for knowledge.

We believe that these structures are needed to understand how, in an institutional culture like the UFRR's, teachers learn teaching from their own educational processes. However, we emphasize that, in this institution, the CCOS and the PPGCOM use internal educational experiences based on the existing relations between the Centers and different Undergraduate courses, although these are still incipient and not institutionalized.

In the Center of Communication, Languages, and Arts (CCLA), the academic unit of which the CCOS and the PPGCOM are part, we can notice the existence of experiences and articulations of different educational possibilities based on integrated actions such as shared disciplines offering, joint events, meetings, and proposals for teaching, research and extension actions that integrate teachers and students that are part of the same educational space.

\section{Teacher education based on the learning of teaching}

In the analysis of the data driven in this study, we sought, based on the public information present in the resumé of professors of the CCOS and the PPGCOM in the Lattes platform and after an inquiry via email related to the activities carried out by them during their education related to the learning of teaching, to present and discuss some categories that would allow us to make some considerations. 


\section{Crevisto \\ e-ISSN n' 2447-4266 \\ Vol. 6, n. 1, January-March. 2020}

To build these categories, we initially propose to present the educational data of the teachers who are part of the analysis corpus of this investigation. Altogether, there are 17 (seventeen) professors (Table 1):

Table 1 Professors in the CCOS the PPGCOM - UFRR 


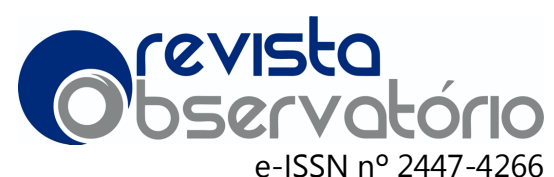

Vol. 6, n. 1, January-March. 2020

\begin{tabular}{|c|c|c|}
\hline & & SOCIAL COMMUNICATION/JOURNALISM COURSE \\
\hline 1 & Professor 01 & $\begin{array}{l}\text { Bachelor's degree in Social Communication/Journalism - UFRR. } \\
\text { Master's degree in Psychology - UCB. } \\
\text { Doctorate in Social History - UFRJ. }\end{array}$ \\
\hline 2 & Professor 02 & $\begin{array}{l}\text { Bachelor's degree in Social Communication/Journalism - UNICENTRO. } \\
\text { Licenciate degree in History - UNICENTRO. } \\
\text { Master's degree in Jornalismo - UFSC. } \\
\text { Doctorate in Modern History - UFF. } \\
\text { Postdoctorate in History - UFAM. }\end{array}$ \\
\hline 3 & Professor 03 & $\begin{array}{l}\text { Bachelor's degree in Social Communication/Journalism - UCPel. } \\
\text { Master's degree in Media Communication - UFSM. } \\
\text { Doctorate in Social Communication - PUCRS, with a period at the University } \\
\text { of Coimbra - Portugal. } \\
\text { Postdoctorate in Philosophy and Human Science - Universidad Nacional } \\
\text { Experimental Simón Rodriguez, Venezuela. }\end{array}$ \\
\hline 4 & Professor 04 & $\begin{array}{l}\text { Licentiate degree in Languages - UFPB. } \\
\text { Bachelor's degree in Social Communication/Journalism - UFPB. } \\
\text { Master's degree in Languages - UFPB. } \\
\text { Doctorate in Languages, Literature and Culture - UFPB. }\end{array}$ \\
\hline 5 & Professor 05 & $\begin{array}{l}\text { Bachelor's degree in Social Communication/Publicity and Advertising - } \\
\text { UNISINOS. } \\
\text { Bachelor's degree in Social Communication/Journalism - UNISINOS. } \\
\text { Master's degree in Comunication Science - UNISINOS. } \\
\text { Doctorate in Communication and Information - UFRGS, with a period at the } \\
\text { Universidade Autônoma de Barcelona - Spain. } \\
\text { Postdoctorate in Languages - UFRR. }\end{array}$ \\
\hline 6 & Professor 06 & $\begin{array}{l}\text { Bachelor's degree in Social Communication/Journalism - UFC. } \\
\text { Master's degree in Communication Science - USP. } \\
\text { Doctorate in Sociology - UFC. }\end{array}$ \\
\hline 7 & Professor 07 & $\begin{array}{l}\text { Bachelor's degree in Social Communication/Journalism-UFJF. } \\
\text { Master's degree in Communication Science - Universidade do Porto, } \\
\text { Portugal. } \\
\text { Doctorate in Communication - UER, with a period at the Curtin University - } \\
\text { Australia. }\end{array}$ \\
\hline 8 & Professor 08 & $\begin{array}{l}\text { Graduação em Licenciatura em Teologia - ISTEP } \\
\text { Bachelor's degree in Social Communication/Journalism - Universidade de } \\
\text { Ribeirão Preto-SP. } \\
\text { Specialization in Social Communication - USF } \\
\text { Master's degree in Education - UFAM. } \\
\text { Doctorate in Communication Science - UNISINOS. }\end{array}$ \\
\hline 9 & Professor 09 & $\begin{array}{l}\text { Bachelor's degree in Social Communication/Journalism - UFRR. } \\
\text { Master's degree in Communication Science - USP. } \\
\text { Doctorate in progress in Contemporary History - Universidade de Évora, } \\
\text { Portugal. }\end{array}$ \\
\hline 10 & Professor 10 & $\begin{array}{l}\text { Bachelor's degree in Social Communication/Journalism - UFRR. } \\
\text { Specialization in Teaching for Higher Education - FAA/RR. } \\
\text { Master's degree in Communication Science - USP. } \\
\text { Doctorate in Media Communication - UFSM. }\end{array}$ \\
\hline 11 & Professor 11 & $\begin{array}{l}\text { Bachelor's degree in Social Communication/Journalism - UFV. } \\
\text { Specialization in Political Journalism (AVM). } \\
\text { MBA in Business Administration (FGV). } \\
\text { Master's degree in Communication - UFJF. } \\
\text { Doctorate in Communication - UFMG. }\end{array}$ \\
\hline
\end{tabular}




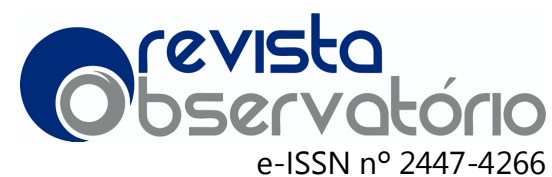

Vol. 6, n. 1, January-March. 2020

\begin{tabular}{|c|c|c|}
\hline 12 & Professor 12 & $\begin{array}{l}\text { Bachelor's degree in Social Communication/Journalism - UFRN. } \\
\text { Specialization in Marketing - Estácio Amazônia. } \\
\text { Master's degree in Education - UFAM. } \\
\text { Doctorate in progress in Education in the Amazon - UFRR. }\end{array}$ \\
\hline 13 & Professor 13 & $\begin{array}{l}\text { Bachelor's degree in Social Communication/Journalism - PUC-Campinas. } \\
\text { Specialization in Intercultural Anthropology - UniEvangélica. } \\
\text { Master's degree in Society and Borders - UFRR. }\end{array}$ \\
\hline 14 & Professor 14 & $\begin{array}{l}\text { Bachelor's degree in Social Communication/Journalism - PUC-Minas. } \\
\text { Master's degree in Communication Processes - UMESP. } \\
\text { Doctorate in Communication - UFSM. }\end{array}$ \\
\hline & \multicolumn{2}{|c|}{ POSTGRADUATE PROGRAM IN COMMUNICATION - PPGCOM } \\
\hline \multicolumn{3}{|c|}{$\begin{array}{c}\text { The professors } 01,02,03,04,05,06 \text {, and } 07 \text { of the Social Communication/Journalism Course are } \\
\text { also part of the PPGCOM/UFRR. }\end{array}$} \\
\hline 15 & $\begin{array}{l}\text { Professor } 15 \\
\text { Works in the } \\
\text { Licentiate } \\
\text { Course in Visual } \\
\text { Arts - UFRR }\end{array}$ & $\begin{array}{l}\text { Bachelor's and Licentiate in degree in Drawing and Plastic Arts - UFSM. } \\
\text { Specialization in Educational Management - UFSM. } \\
\text { Master's degree in Cultural Heritage - UFSM. } \\
\text { Master's degree in Education - UFSM. } \\
\text { Doctorate in Education - UFSM, with a period at the Universidade de Lisboa } \\
\text { - Portugal. } \\
\text { Postdoctorate in Philosophy and Human Science - Universidad Nacional } \\
\text { Experimental Simón Rodriguez - Venezuela. }\end{array}$ \\
\hline 16 & $\begin{array}{c}\text { Professor } 16 \\
\text { Works in the } \\
\text { Licentiate } \\
\text { Course in Music } \\
\text { - UFRR }\end{array}$ & $\begin{array}{l}\text { Bachelor's degree in Music - UPF. } \\
\text { Master's degree in History - UPF. } \\
\text { Doctorate in Music - UFBA, with a period at the University of Montana - } \\
\text { United States. } \\
\text { Postdoctorate in Arts and Musicology at the University of Trás-os-Montes and } \\
\text { Alto Douro - Portugal. }\end{array}$ \\
\hline 17 & $\begin{array}{c}\text { Professor } 17 \\
\text { Worked in the } \\
\text { Licentiate } \\
\text { Course in Visual } \\
\text { Arts - UFRR }\end{array}$ & $\begin{array}{l}\text { Licentiate degree in History - UFRPE. } \\
\text { Master's degree in Social History and Regional Culture - UFRPE. } \\
\text { Doctorate in History - UFPE. }\end{array}$ \\
\hline
\end{tabular}

The analysis categories defined were: 1 - Initial academic education, where we present the initial education of the teachers and relate them to the possibilities and elements of teacher education; 2 - Postgraduate studies, where we present the education and, consequently, the possibilities of disciplines and educational actions taken at this level; and, lastly, 3 - Educational trajectories, where we present, based on reports provided, some other educational experiences that made the learning of teaching process possible.

About the Initial academic education of the teachers of the CCOS and the PPGCOM, the predominance of professors with a Bachelor's degree is clear. Altogether 15 (fifteen) of the 17 (seventeen) teachers have a Bachelor's degree as their first education - 12 (twelve) of them have a Bachelor's degree in Social Communication specialized in Journalism and/or its variants; 01 (one) teacher has a Bachelor's degree in Social 


\section{revisto \\ Observatório

Vol. 6, n. 1, January-March. 2020

Communication specialized in Publicity and Advertising; and 02 (two) other teachers with Bachelor's degrees in the areas of Drawing and Plastic Arts, and Music.

Only 03 (three) teachers have a Licentiate degree as their first academic degree one has a Licentiate degree in Languages, another one in History, and the other one in Theology. And 02 (two) more teachers have Licentiate degrees as a second higher education degree - one in the area of Drawing and Plastic Arts, and the other one in History. There is also 02 (two) teachers with a second degree - Bachelor's degree in Social Communication/Journalism.

The data analysis makes clear at least two main nuances present in the initial educational processes of the teachers of the CCOS and the PPGCOM. Because the courses are contained in the great area of Communication and Information, what predominates is the initial education of teachers that were not trained to be teachers. The area oof Communication is by nature an area of Bachelor's courses and it is there that most of the analyzed faculty members sought their first professional qualification.

Such finding reflects part of the process of maturity of the Communication Field in Brazil. Most of the professors analyzed are part of a second (or third) generation of teachers forged already within the Communication Field itself. In contrast to this, it is known that the founding professors and researchers of this area in Brazil, for the most part, came from other fields where Licenciate courses were more common.

According to Willians (1969, p. VIII), the history of culture, the history of a context "[...] must be more than the sum of the individual histories, because it is with the relations between them, the particular forms of the total organization, with which it is especially concerned" ${ }^{\prime \prime}$. The author highlights in this excerpt his concern not only with the historicity of academic culture but with the relations that are established between culture and the subjects belonging to that space/place and time.

The dimensions of the teaching culture and the academic culture are, therefore, determinant aspects for the realization of the understanding of the learning to be a teacher, considering that it is not possible to think of a subject outside the context of education and practice. We then consider, according to Leontiev (1984), that human work cannot be excluded from relations with the social and cultural space, that is, from the life in society, which we form and which form us.

\footnotetext{
9 "[...] deve ser mais do que a soma das histórias particulares, pois é com as relações entre elas, as formas particulares da organização total, que ela está especialmente preocupada."
} 


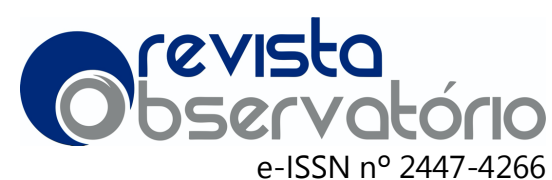

Vol. 6, n. 1, January-March. 2020

From this perspective, this study pursues a closer look at teacher education and also at the cultural-historical context of the work of the CCOS and the PPGCOM professors.

The clear lack of pedagogical training, evidenced by the innocuous contact with the licentiate courses in the process of the teachers' initial education, meant that some of the professors sought to improve their abilities to teach already in Postgraduate Programs, in Specialization courses. Of the 06 (six) professors with Specialization degrees, 02 (two) sought qualification in areas related to Education - 01 (one) teacher has a Specialization in Teaching in Higher Education and the other one in Educational Management. The other 03 (three) are Specialized in áreas related to Journalism and 01 (one) in the area of Anthropology.

When we analyze the qualifications at the Master's level, it is also clear that the professors are concerned with improving their knowledge in areas related to their initial education, predominantly related to the Communication field. However, greater variability was found in these educational experiences. There are 09 (nine) teacher with a Master's degree in Communication, Communication Sciences, Communication Processes, Media Communication, and/or Journalism and its variants. Three (03) professors, however, had their Master's degree in Education - one of them also had a Master's degree in Cultural Heritage. Of the other teachers, 02 (two) have a Master's degree in History or Social History; 01 (one) has a Master's degree in Psychology; 01 (one) has a Master's degree in Languages; and 01 (one) has a transdisciplinary master's degree in Society and Borders.

Regarding Doctorate, the qualification of the analyzed teachers also predominates in courses related to the Communication Field. Seven (07) of them had doctorates in Social Communication, Media Communication, Communication and Information, or Communication Sciences. This level, however, has a reversal of trend, with most of the teachers having their education in other fields of knowledge: 04 (four) have doctorates in History (01 in progress); 02 (two) have doctorates in Education (01 in progress); 01 (one) has a doctorate in Sociology; 01 (one) in Languages; 01 (one) in Music; and 01 still has not started their doctoral studies.

Of these, 06 (six) professors have had experiences abroad, doing all or part of their doctoral process outside the country. Of the total number of professors, 05 (five) have also developed projects of Postdoctoral research - 02 (two) of them in the country, in the History and Language areas; and 03 (three) of them abroad, in the areas of Philosophy and Human Science, and Art and Musicology. 


\section{Observistotório \\ e-ISSN no $2447-4266$}

Vol. 6, n. 1, January-March. 2020

At this level, the data show a shift in the priority education axis of the teachers from the Communication Field to other fields of knowledge. Based on the Specializations, we can notice a progressive approach with different fields of knowledge (closer to Licentiate degrees), especially the fields of Education, History, and Transdisciplinary, with the desire to perhaps fill the gaps in their pedagogical education or for working in the classroom.

This journey, according to Isaia and Bolzan (2007, p. 110) shows us that "the personal and professional trajectories are defining factors of the professors' mode of action, revealing their conceptions about the pedagogical practice ${ }^{\prime 10}$. And, as already mentioned, we can see that the master's and doctor's degrees bring someone closer to the teacher education, given the professional direction taken towards the field of teaching in higher education.

Such trend is even more evident from the Doctorate level, at which most of the teachers analyzed, despite still having a strong bond with the Communication Field, seek qualification in other fields of knowledge - as pointed out, 09 of them have already taken or are taking their doctorates in other areas.

It is obvious that, when it comes to formal education in a region like the Amazon and the context of Roraima, we also need to consider the element of opportunity as a decisive factor in choosing which way to go. In many cases, there is (or there were) no choices other than teacher education and one end up looking for a qualification in the courses, programs and/or areas of knowledge that were accessible to them. The fact that only 03 (three) of the teachers of the CCOS and the PPGCOM have completed part of their education in Roraima or the Northern Region corroborates with such observation.

This denotes the search for education in teaching training in other HEls. This search certainly comes from the local cultural-historic educational need, and after the teacher's return, there is the sharing of knowledge between peers, considering that they "bring with them personal and socio-cultural elements, in addition to anonymous collaborations, making them someone designed for the future, an individual who contributes to produce and build novelties, transforming his present"11 (ISAIA; BOLZAN, 2007, p. 173). However, it is clear that this knowledge sharing is still incipient and informal in the practice of the CCOS and the PPGCOM teachers, and that institutional strategies in this regard need to be improved.

\footnotetext{
10 "as trajetórias pessoais e profissionais são fatores definidores dos modos de atuação do professor, revelando suas concepções sobre o fazer pedagógico"

11 "traz consigo elementos pessoais e socioculturais, além de colaborações anônimas, fazendo dele um sujeito projetado para o futuro, um indivíduo que contribui para produzir e construir novidades, transformando o seu presente"
} 


\section{Orevisto \\ e-ISSN n' 2447-4266}

Vol. 6, n. 1, January-March. 2020

In the category of Educational trajectories, we sought to list, from reports sent by the teachers themselves, some of the other most significant experiences that made the learning of teaching process possible. Such educational experiences ended up configuring some of the main trajectories which we will detail next. It is clear that the educational trajectory involves the articulation of personal and professional experiences in different educational stages, however, we will try to enter here in more detail the undergraduate and postgraduate stages as an educational locus for the learning of teaching (ISAIA and BOLZAN, 2007).

The articulation of educational trajectories in academic culture provides the construction of professorship which, according to Isaia and Bolzan (2007), involves the efforts of teachers and institutions from which the articulation of mediation spaces where the sharing of specific, pedagogical and professional knowledge is the lever for the construction of this professorship.

This, when addressing the educational trajectories of the studied professors, we can see that some of them are bound to the processes of teaching and learning of teaching developed in postgraduation studies. In addition to the aforementioned Specialization, Master's, and Doctor's levels of education, the experiences of Teaching Internship and/or Assisted Teaching also stand out - these are frequent components in Postgraduate Programs and are mandatory items in most curriculums for scholarship students, who had their studies financed by some funding agency.

In the CCOS and the PPGCOM, in Roraima, in the Northern Region and perhaps even in Brazil, it seems reasonable to assume that it is the scholarship students of the Postgraduate Programs that take on the role of teachers in higher education. This fact does not seem to be pure coincidence.

Of the CCOS and PPGCOM faculty members, 09 (nine) reported having experiences in Teaching Internship and/or Assisted Teaching in the Undergraduate Courses (mostly Social Communication/Journalism) in the Universities where they took their Master's or Doctoral studies. For some, especially the ones that had a Bachelor's degree as their first education level, this was their first (and definitive) experience in teacher education and that's why we highlight its importance.

Another educational experience related to postgraduate studies that appear in the teachers' reports is the specific courses taken during their trajectories. At least 04 (four) of them reported having taken courses such as Higher Education Methodology; Alternative Learning Methodologies; Education Journeys in Higher Education Teaching; Teaching Improvement Program, etc. in their master's or doctoral studies. 


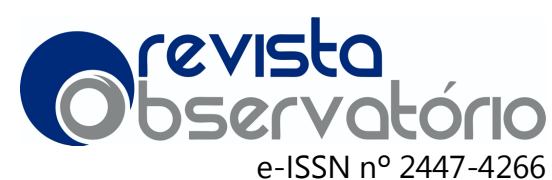

Vol. 6, n. 1, January-March. 2020

These two types of experiences that were reported therefore denote that, for the professors in the CCOS and PPGCOM, the Postgraduate studies are indeed an important (and in some cases nearly definitive) locus to the learning of teaching.

Educational trajectories related to the processes of teaching and learning of teaching carried out at the Undergraduate level also appear in the reports. In this stage, the Teaching Internships, which are mandatory for the Licentiate courses and are conducted exclusively in Municipal or State Public Schools, cannot be overlooked, since 04 (four) of the CCOS and the PPGCOM faculty members have a licentiate degree.

Scientific Initiation Projects and Teaching Assistance Programs conducted within Undergraduate courses were mentioned by 03 (three) teachers as important elements in their educational trajectories; as well as Special Projects of Extension or Teaching, such as Workshops, Short Courses, free Preparation Courses for College Admittance, etc. mentioned by other 03 (three) teachers.

It is worth mentioning, therefore, that in addition to Licentiate programs, the learning of teaching can also happen in other educational spaces of Undergraduate studies and that, at least for the teaching staff considered, these spaces are also relevant in the whole of the educational trajectories.

Concerning Market Experience, the reports point out the teachers' experiences in the Education Market. In this axis, we can pinpoint four main trajectories. The practice as a Professor Hired in Private or Community Universities is the main way of entry into the education market for 08 (eight) of the teachers of the CCOS and the PPGCOM. Following is the practice as a Substitute Teacher in Technical Schools or Public Universities, pointed out as a way of entering the education market by 07 (seven) of the professors. Also worth mentioning are their experiences and practice as teachers in Private or Public Schools of Secondary or Elementary Education - 04 (four) of them share this experience. Also, the adventure of private lessons is reported as an important teaching experience by 02 (two) other teachers.

It is worth noting, however, that before the regime of Exclusive Dedication to the UFRR, today shared by the 17 of the CCOS and the PPGCOM faculty members, it was common for them to work simultaneously in more than one front of work in education. This versatility, we believe, contributed with unique features to this teacher education process.

Of the teachers' Market Experiences, we can also mention the ones related to Distance Education. Three (03) of the CCOS and the PPGCOM professor reported having worked as a teacher, in the production of didactic material, in project management, in 


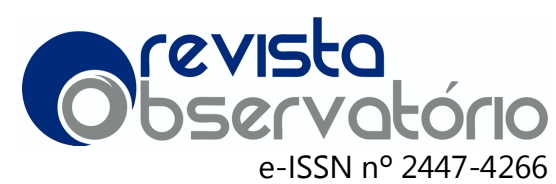

Vol. 6, n. 1, January-March. 2020

methodological and pedagogical actions for distance learning or coordinating Distance Education Centers.

Past experiences such as working as agents of development, rural extended education, special projects of education or extension, short courses and workshops also appear as important educational experiences for 03 (three) of the teachers in their reports.

The experiences presented by the teachers establish their educational trajectories and lead up to a constant process of the learning of teaching. This is made clear by the report of professor 16, 15, 11, and 06 when they state that:

I have worked on several subjects, some close to my area of study, but also in everything else that the others did not want to teach. Even interdisciplinary curriculum components. (Teacher 16, 2020)

I have had several experiences from basic to higher education. The sharing relationship with colleagues and the collective learning at times were fundamental. However, it is worth noting that sometimes the will to engage in different activities was blocked and/or discouraged by a practice of teaching already embedded in the school and university environment. (Teacher 15, 2020)

I also believe that in addition to having good teaching skills, it is necessary, especially in higher education at public universities, to have the ability to "be a teacher" outside the classroom and to engage in projects of extension and research that might be able to catalyze the human aspect of student's education. (Teacher 11, 2020).

One was determined by the need to build and improve the Course in several actions, such as the first versions of the Pedagogical Project and the promotion of scientific events at especially challenging times for the higher education in the Northern region; the other one was related to the inter-institutional master's course. Research and everything that orbits it reinforces the teaching profession. The same goes for my doctorate. (Teacher 06, 2020).

By the teachers' reports, we can highlight the continuous factor of the learning of teaching and the challenge factor for their professionalization, both in terms of the classroom and in terms of administrative work. The reports demonstrate contact with the teaching practice that is permeated by the subject's desire to perform it. For them, identification with the teaching profession happens in this way and also, mainly from experience and with the perception of the educational and intervention needs that happen in the subject's dialogue with their socio-cultural context (VYGOTSKI, 1995).

The professors who took part in the research reported some educational experiences related to the teaching practice and these are the moments when they start 


\section{revisto \\ Observatório \\ e-ISSN no 2447-4266}

Vol. 6, n. 1, January-March. 2020

the process of making their own conscience and trigger reflections that will make them aware of their choices and their educational needs.

\section{Final remarks}

Throughout this study, we found that the educational processes experienced by each teacher outline aspects ranging from initial education to the beginning of their teaching practice. Each teacher, based on their experiences in education and/or practice areas, has some unique needs. Isaia and Bolzan (2008) point out that in addition to the intersubjective and intrasubjective relations and the relations of a teacher as a person, the essential thing is also to understand how teachers face these crises and their challenges.

Thus, the experience of "conflicts" can be seen as an essential component to the education of the teachers of the CCOS and the PPGCOM as it comprises the relation between the individual and the collective professional selves, representing the tortuous path to be followed by the teachers aiming to solve their crises and challenges. Its essence is the movement and the search through which teachers feel safe with subjects and groups as they find, in the center of the labyrinth, their true self.

This professional self is constituted in the relation of the teacher as an individual and as a group and, in this sense, the conversation with colleagues and the experiences in the workplace emerge as an extra incentive for the teacher to face the challenges in their work area. In this way, it is clear that learning the teaching practice involves the students' educational development and the teacher self-educating.

To the extent that teachers educate, they are also educated and that process required a collaborative posture that is made by practice in the classroom. It is a social and shared achievement.

The process of learning of teaching places the teacher in face of a challenge of using strategies to favor the mastery of specific knowledge, articulating with the pedagogical dimension. Thus, based on this relation "[...] it is possible to understand the intrinsic relation between educational processes and educational trajectories because both consist of the constructive movement of teachers"12 (ISAIA e BOLZAN, 2008, p. 122).

Thus, it can be seen that the mastery of specific knowledge articulated with the pedagogical dimension is triggered by different times and factors experience before or during teacher education. It is, therefore, in the conversation with others, in the

12 "[...] é possível compreendermos a intrínseca relação entre processos formativos e trajetórias de formação, pois ambos compreendem o movimento construtivo dos professores" 


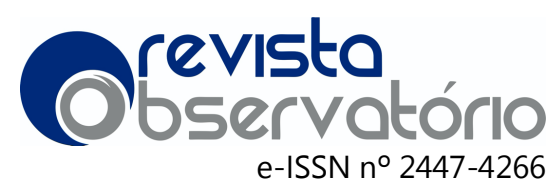

Vol. 6, n. 1, January-March. 2020

articulation with other types of knowledge and in facing challenges that the teacher starts to face their limits and perceive their possibilities of education and practice.

\section{References}

BAPTAGLIN, L. A. Aprendizagem da docência: um olhar para os cursos técnicos de ensino médio integrado. Curitiba: Appris, 2017.

BATISTA, T. M. M. A Formação continuada de professores do curso de direito e as possibilidades de desenvolvimento da prática docente reflexiva crítica. Tese de doutorado do Programa de Pós-Graduação em Educação da UFPI, 2017.

BOLZAN, D. P. V. Aprendizagem Docente e Processos Formativos: Nova perspectivas para a Educação Básica e Superior. Projeto de Pesquisa Interinstitucional e Integrado (02-1734-2). Relatório de pesquisa. CNPQ - PPGE/CE/UFSM, 2008.

BOLZAN, D. P. V.; ISAIA, S. M. A. Aprendizagem colaborativa: processos formativos em construção. Anais da VII Anped Sul, Itajaí/SC, 2008.

DEBUS, I. S. Imaginários, saberes e fazeres no ensino superior: processos formativos do formador de professores. Tese de doutorado do Programa de Pós-Graduação em Educação da UFSM, 2017.

ENGERS, M.E. A.; MOROSINI, M. C. (Org.) Pedagogia Universitária e Aprendizagem. V.2. Série Ries/PROMEX. Porto Alegre: EdiPUCRS, 2007.

FERRY, G. Pedagogía de la formación. $-1^{\circ}$ ed. $1^{\circ}$ reimp. Buenos Aires: Centro de publicaciones educativas y material didáctico, 2004.

HAUTRIVE, G.F. Aprendizagem docente do professor surdo: a produção de saberes sobre a escrita da língua de sinais. Tese de doutorado do Programa de PósGraduação em Educação da UFSM, 2016.

ISAIA, S. M. A; BOLZAN, D. P. V. Construção da profissão docente/professoralidade em debate: desafios para a educação superior. In: CUNHA, Maria Isabel (org.). Reflexões e práticas em pedagogia universitária. Campinas, SP: Papirus, 2007.

ISAIA, S. M. A; BOLZAN, D. P. V. Compreendo os movimentos construtivos da docência superior: construções sobre pedagogia universitária. Linhas críticas, Brasília, V.14, N.26, p.43-59, Jan./Jun. 2008.

LEONTIEV, A. N. Actividad, Conciencia, Personalidad. México: Editorial Cartago de México, 1984.

MACIEL, A. M. A geratividade docente na Educação Superior e os movimentos (trans) formativos para o desenvolvimento profissional. In: ISAIA, S. M. A; BOLZAN, D. P. V. 


\section{Crevisto \\ Observatório \\ e-ISSN n 2447-4266}

Vol. 6, n. 1, January-March. 2020

(Org.). Pedagogia universitária e desenvolvimento profissional docente. V.4. Série Ries/PROMEX. Porto Alegre: EdiPUCRS, 2008.

POZZO, J. I .Aprender en la sociedad de conocimiento. In: ENGERS, M. E. A.; MOROSINI,

M. C. (Org.) Pedagogia Universitária e Aprendizagem. V.2. Série Ries/PROMEX. Porto Alegre: EdiPUCRS, 2007.

SANDRI, V. Aprendizagem docente no ensino superior: processos formativos de professores e estudantes nas licenciaturas da área de ciências biológicas, exatas e da terra. Tese de doutorado do Programa de Pós-Graduação em Educação da UFSM, 2017.

SANTANA, A. F. T. Um olhar acerca do sentido da experiência na formação de professores. Tese de doutorado do Programa de Pós-Graduação em Educação da UFRGS, 2017.

SILVA, G. T. A aprendizagem da prática docente no Programa de Pós-Graduação em Administração. Tese de doutorado do Programa de Pós-Graduação em Administração da UFPB, 2017.

TAVARES, J. Ser um Educador em Tecnologia. In: ENGERS, M. E. A.; MOROSINI M. C. (Org.) Pedagogia Universitária e Aprendizagem. V.2. Série Ries/PROMEX. Porto Alegre: EdiPUCRS, 2007.

UFRR. Projeto Pedagógico do Curso de Comunicação Social-Jornalismo. 2015.

Disponível em:

https://www.dropbox.com/s/ihn1s1k3sslnw3i/Projeto\%20Político\%20Pedagógico. pdf?dl=0. Acesso em: 21 de jan. 2020.

UFRR. Regimento do PPGCOM/UFRR. 2018. Disponível em: file:///C:/Users/lab25/AppData/Local/Packages/Microsoft.MicrosoftEdge_8wekyb3 d8bbwe/TempState/Downloads/regimento\%20ppgcom\%20(1).pdf. Acesso em: 21 de jan. 2020.

UFRR. Resolução n 001/2017 - CUNE. Aprova o Plano de Desenvolvimento Institucional - PDI (2016-2019), 2017. Disponível em:

file:///C:/Users/lab25/AppData/Local/Packages/Microsoft.MicrosoftEdge_8wekyb3 d8bbwe/TempState/Downloads/PDI\%2020162019\%20APROVADO\%20CUNI\%20(1).pdf. Acesso em: 21 de jan. 2020.

UFRR. Resolução n 026/2003-CUNI. Aprova o novo Estatuto da Universidade Federal de Roraima - UFRR, 2003. Disponível em: file:///C:/Users/lab25/AppData/Local/Temp/estatuto\%20ufrr\%20modificaes\%20e\% 20atualizaes\%20jul2013.pdf. Acesso em: 21 de jan. 2020. 


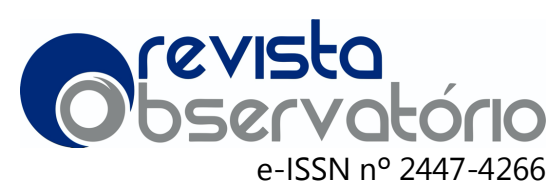

Vol. 6, n. 1, January-March. 2020

WILLIANS, R. Cultura e sociedade. São Paulo: Editora Naciona,1969.

VYGOSTKI, L. S. Obras escolhidas III: incluye problemas de desarollo de la psique. Madri-

Espanha: Visor, 1995.

\section{RESUMO:}

A presente investigação objetiva discutir a formação docente realizada na construção da aprendizagem da docência dos professores que atuam nos cursos de Bacharelado em Comunicação Social/Jornalismo (CCOS) e no Programa de Pós-Graduação em Comunicação (PPGCOM) da Universidade Federal de Roraima (UFRR). Para isso, fizemos uma análise dos Currículos Lattes e uma consulta via e-mail aos docentes indagando-os sobre as atividades realizadas durante $o$ processo de sua formação, vinculadas à aprendizagem da docência. Esse conjunto de documentos foi investigado a partir da Análise de Conteúdo na qual foram acionadas três categorias: Formação inicial acadêmica; Pós-Graduação; e, Trajetórias formativas. O que fica evidente com a discussão dos dados é que, na medida em que os professores são formadores, também se formam e este processo exige uma postura colaborativa que se faz na prática da sala de aula, é uma conquista social, compartilhada. O processo de aprendizagem da docência coloca, portanto, o professor diante do desafio de se apropriar de estratégias capazes de favorecer o domínio dos conhecimentos específicos, articulando-os com a dimensão pedagógica, mesmo que para isso tenha que acionar experiências formativas outras que não necessariamente passem pela educação formal.

PALAVRAS-CHAVE: Aprendizagem da docência; Formação docente; Comunicação; Saberes Amazônicos; Universidade Federal de Roraima.

\section{RESUMEN:}

La presente investigación tiene como objetivo discutir la formación de docentes realizada en la construcción de la enseñanza docente de los docentes que trabajan en los cursos de Bachillerato en Comunicación Social / Periodismo (CCOS) y en el Programa de Postgrado en Comunicación (PPGCOM) de la Universidad Federal de Roraima (UFRR). ) Para ello, realizamos un análisis de los Currículos Lattes y consultamos por correo electrónico a los docentes preguntándoles sobre las actividades realizadas durante el proceso de su formación, vinculadas a la enseñanza aprendizaje. Este conjunto de documentos se investigó a partir del análisis de contenido en el que se activaron tres categorías: capacitación académica inicial; Posgraduación; $y$, Trayectorias formativas. Lo que es evidente con la discusión de los datos es que, como los maestros son entrenadores, también se gradúan y este proceso requiere una postura de colaboración que se realiza en el aula, es un logro social y compartido. El proceso de enseñanza aprendizaje, por lo tanto, coloca al maestro frente al desafío de apropiarse de estrategias capaces de favorecer el dominio de conocimiento específico, articulándolos con la dimensión pedagógica, incluso si para eso tiene que desencadenar experiencias de capacitación que no sean necesariamente pasar por la educación formal.

PALABRAS-CLAVES: Aprendizaje de la ensenanza; Formación del profesorado; Comunicación; Conocimiento amazónico; Universidad Federal de Roraima. 